\title{
BIOREMEDIATION OF SOIL CONTAMINATED BY DIESEL OIL
}

\author{
Fatima Menezes Bento ${ }^{1 *}$; Flávio Anastácio de Oliveira Camargo ${ }^{1}$; \\ Benedict Okeke²; Willian Thomas Frankenberger-Júnior ${ }^{2}$
}

\author{
${ }^{1}$ Departamento de Solos, Universidade Federal do Rio Grande do Sul, Porto Alegre, RS, Brasil. ${ }^{2}$ Department of Environmental \\ Science, Geology Building, University of California, Riverside, USA.
}

This paper corresponds to an "extended abstract" selected for oral presentation in the $22^{\text {nd }}$ Brazilian Congress of Microbiology, held in Florianópolis, SC, Brazil, in November 17-20, 2003

\begin{abstract}
Were evaluated natural attenuation, biostimulation and bioaugmentation on the degradation of total petroleum hydrocarbons (TPH) in soils contaminated with diesel oil. Bioaugmentation showed the greatest degradation in the light $\left(\mathrm{C}_{12}-\mathrm{C}_{23}\right)$ fractions $(72.7 \%)$ and heavy $\left(\mathrm{C}_{23}-\mathrm{C}_{40}\right)$ fractions of TPH $(75.2 \%)$ and natural attenuation was more effective than biostimulation. The greatest dehydrogenase activity was observed upon bioaugmentation of the Long Beach soil (3.3-fold) and the natural attenuation of the Hong Kong soil sample (4.0-fold). The number of diesel oil degrading microorganisms and heterotrophic population was not influenced by the bioremediation treatments. The best approach for bioremediation of soil contaminated with diesel oil is the inoculum of microorganisms pre-selected from their own environment.
\end{abstract}

Key words: natural attenuation, bioagmentation, biostimulation, total petroleum hydrocarbon.

\section{INTRODUCTION}

Bioremediation is a popular approach of cleaning up petroleum hydrocarbons because it is simple to maintain, applicable over large areas, cost-effective and leads to the complete destruction of the contaminant (5). Strategies for inexpensive and clean in situ bioremediation of soil contaminated with diesel oil include stimulation of the indigenous microorganisms, by introducing nutrients and oxygen into the soil (biostimulation) (6) or through inoculation of an enriched mixed microbial consortium into soil (bioaugmentation) (2). To demonstrate the potential use of bioremediation in soil contaminated with diesel oil, we performed a laboratory study with the goal of evaluating the effects of natural attenuation, biostimulation and bioaugmentation on diesel oil degradation.

\section{MATERIALS AND METHODS}

Two diesel oil contaminated soils were collected from Long Beach, California (USA) and Hong Kong (China) (Table 1). The hydrocarbon-degrading bacterial consortium used were those previously isolated from the Long Beach soil, identified by $16 \mathrm{~S}$ rRNA gene sequence as Bacillus cereus, Bacillus sphaericus, Bacillus fusiformis, Bacillus pumilus, Acinetobacter junii and Pseudomonas sp. (3). Contaminated soils (450 g samples) were placed in a set of aluminum pan, and aerated by mixing. The microcosms was kept at room temperature $\left(27^{\circ} \mathrm{C}\right)$ and moistened every week. The control was sterilized three times by autoclaving. The soils were biostimulated by adding $250 \mathrm{mg} \mathrm{kg}^{-1}$ of $\left(\mathrm{NH}_{4}\right)_{2} \mathrm{SO}_{4}$ and $100 \mathrm{mg} \mathrm{kg}^{-1}$ of $\mathrm{K}_{2} \mathrm{HPO}_{4}$. The same conditions provided in the biostimulation treatment were used in the bioaugmentation treatment plus the addition of $40 \mathrm{~mL}$ of $2.610^{8} \mathrm{cells} \mathrm{mL}^{-1}$ of a

*Corresponding author. Mailing address: Av. Bento Gonçalves, 7712. 91540-000, Porto Alegre, RS, Brasil. Tel.: (+5551) 3316-6024. Fax: (+5551) 3316-6023. E-mail: fatimabento@yahoo.com 
Table 1. Physical and chemical characteristics of soils.

\begin{tabular}{lccccccccc}
\hline \multicolumn{1}{c}{ Soil sample } & $\mathbf{p H}(\mathbf{1}: \mathbf{1})$ & $\mathbf{C E C}$ & $\begin{array}{c}\text { Organic } \\
\text { Matter }\end{array}$ & Total N & Sand & Silt & Clay & $\mathbf{T P H}\left(\mathbf{C}_{12}-\mathbf{C}_{23}\right)$ & $\mathbf{T P H}\left(\mathbf{C}_{23}-\mathbf{C}_{40}\right)$ \\
\hline & & $\mathrm{cmol}_{\mathrm{c}} \mathrm{kg}^{-1}$ & & & $\mathrm{~g} \mathrm{~kg}^{-1}$ & & & & $\mathrm{mg} \mathrm{kg}^{-1}$ \\
Long Beach & 6.3 & 6.2 & 25.9 & 2.38 & 610 & 320 & 70 & 2,800 & 9,450 \\
Hong Kong & 7.7 & 10.8 & 65.5 & 1.85 & 780 & 150 & 70 & 3,300 & 7,450 \\
\hline
\end{tabular}

bacterial consortium previously isolated from the Long Beach soil. The contaminated soils were sampled at $0,1,2,6,8$ and 12 weeks for chemical and microbiological analyses. Total petroleum hydrocarbon (TPH) was determined using a modified EPA 8015 technique, using a gas chromatograph (HP 5890) equipped with a flame ionization detector (FID). Percentage of degradation was calculated by the following expression: $\%$ of degradation $=[($ TPH control - TPH treatment $) /$ TPH control $] \mathrm{x}$ 100. Microbial cell numbers were estimated using the most probable number (MPN) method and the reaction with tetrazolium chloride (TTC) for diesel-fuel degrading microorganisms, indicating reduction of the tetrazolium dye via respiration for the diesel oil-degraders. Microbial populations were determined using statistical tables and soil microbial activity was estimated by the dehydrogenase assay according to Alef (1).

\section{RESULTS}

After 12 weeks of incubation, the greatest percentage of degradation of the light (75\%) and heavy fractions of TPH (73\%) was observed in the Long Beach soil when pre-selected bacteria were added to the microcosm (bioaugmentation) (Table 2). This pattern was also observed in the weekly rate of degradation, where bioaugmentation was responsible for the highest degradation rates in both fractions of TPH of the Long Beach soil. Addition of nutrients (biostimulation) had the least effect on the degradation of both fractions of TPH in both soils. Between the two soils, the Long Beach sample showed the most degradation in both TPH fractions. In the Hong Kong soil, a higher percentage of degradation was found upon natural attenuation of the light fraction (Table 2).

Dehydrogenase activity varied, depending on the incubation time, bioremediation treatments and soils (Fig.1). Increasing the incubation time increased the relative activity of dehydrogenase in both soils, and, on the average, the highest activity was found upon bioaugmentation of the Long Beach soil. Among the bioremediation treatments in the Hong Kong soil, the highest microbial activity was found upon $\mathrm{n}$. The number of diesel oil-degrading microrganisms was highest in the Long Beach soil in the first week and decreased after the second week (Fig. 2). In this soil, the addition of pre-selected bacteria (bioaugmentation) or nutrients (biostimulation) resulted
Table 2. Cumulative percentage of degradation and weekly rate of degradation of the light and heavy fractions of total petroleum hydrocarbons present in two soils contaminated with diesel oil.

\begin{tabular}{|c|c|c|c|c|}
\hline \multirow{2}{*}{ TPH fractions } & \multicolumn{2}{|c|}{ Light fraction } & \multicolumn{2}{|c|}{ Heavy fraction } \\
\hline & $\left(\mathbf{C}_{1}\right.$ & $\left.\mathbf{C}_{23}\right)$ & $\left(\mathbf{C}_{23}\right.$ & $\left.\mathbf{C}_{40}\right)$ \\
\hline Soils & $\begin{array}{l}\text { Long } \\
\text { Beach }\end{array}$ & $\begin{array}{l}\text { Hong } \\
\text { Kong }\end{array}$ & $\begin{array}{l}\text { Long } \\
\text { Beach }\end{array}$ & $\begin{array}{l}\text { Hong } \\
\text { Kong }\end{array}$ \\
\hline treatments & & & \multicolumn{2}{|c|}{$\%$ of degradation 1} \\
\hline Attenuation & 48.7 & 23.3 & 45.7 & 7.5 \\
\hline Biostimulation & 45.8 & 16.0 & 45.2 & 6.2 \\
\hline Bioaugme & 75.2 & 17.8 & 72.7 & 7.3 \\
\hline treatments & & & \multicolumn{2}{|c|}{$\begin{array}{c}\text { Weekly } \\
\text { degradation rate }\end{array}$} \\
\hline Attenuation & 0.451 & 0.000021 & 0.205 & 0.105 \\
\hline Biostimulation & 0.324 & 0.000008 & 0.106 & 0.00012 \\
\hline Bioaugmentation & 0.577 & 0.000011 & 0.296 & 0.0405 \\
\hline
\end{tabular}

${ }^{1}$ Percentage of degradation cumulated in the end of the $12^{\text {th }}$ week; ${ }^{2}$ Estimated using the cumulative degradation data (mg $\mathrm{TPH} \mathrm{kg}{ }^{-1}$ soil) and the exponential rise to maximum equation: Degradation $=$ Degradation $_{\max }\left(1-\mathrm{e}^{-\mathrm{kt}}\right)$, to obtain the rate constant of degradation $\mathrm{k}$.

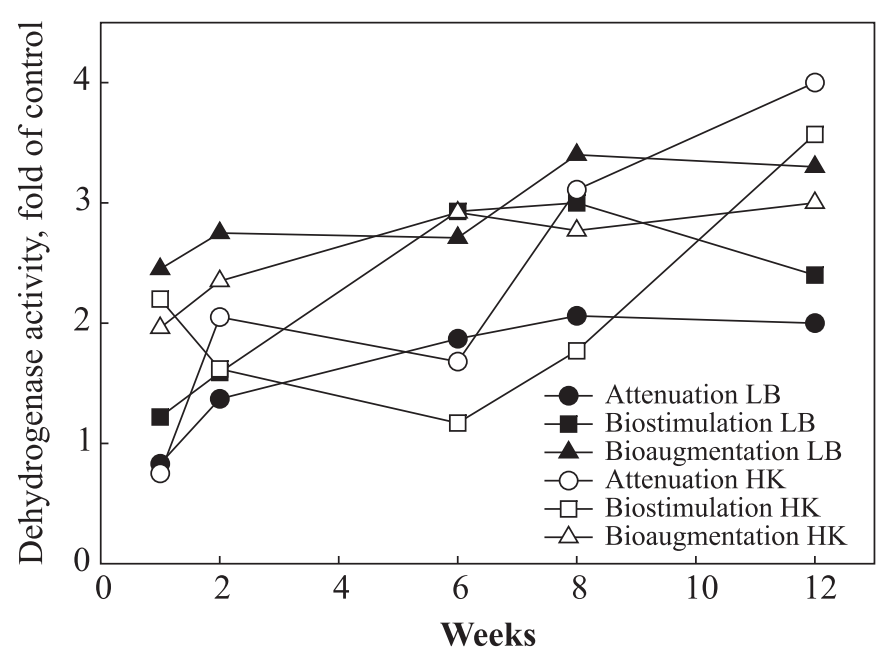

Figure 1. Microbial activity estimated by dehydrogenaserelated activity (relative to the control) of soils Long Beach (LB) and Hong Kong (HK) contaminated with diesel oil. 
Table 3. Number of total heterotrophic microorganisms present in soils contaminated with diesel oil.

\begin{tabular}{|c|c|c|c|c|c|c|}
\hline \multirow[b]{2}{*}{ Weeks } & \multicolumn{3}{|c|}{ Long Beach soil } & \multicolumn{3}{|c|}{ Hong Kong soil } \\
\hline & Attenuation & Biostimulation & Bioaugmentation & Attenuation & Biostimulation & Bioaugmentation \\
\hline & & & & & og bacteria $\mathrm{mI}$ & \\
\hline 01 & $7.35(0.67)^{1}$ & $9.15(0.79)$ & $8.61(0.87)$ & $5.59(0.68)$ & $5.27(1.04)$ & $6.10(0.78)$ \\
\hline 02 & $7.90(0.38)$ & $8.50(0.39)$ & $8.90(0.43)$ & $5.20(0.84)$ & $5.90(0.76)$ & $6.40(0.72)$ \\
\hline 06 & $5.89(0.56)$ & $6.38(0.55)$ & $6.11(0.59)$ & $5.69(0.85)$ & $5.84(0.80)$ & $6.07(0.81)$ \\
\hline 08 & $5.38(0.78)$ & $5.69(0.46)$ & $6.38(0.71)$ & $5.69(0.83)$ & $5.54(0.89)$ & $5.84(0.97)$ \\
\hline 12 & $7.96(0.42)$ & $7.32(0.48)$ & $6.89(0.57)$ & $7.96(0.58)$ & $7.38(0.51)$ & $8.38(0.50)$ \\
\hline
\end{tabular}

${ }^{1}$ Ratio of diesel oil-degrading microrganisms / heterotrophic microorganisms.

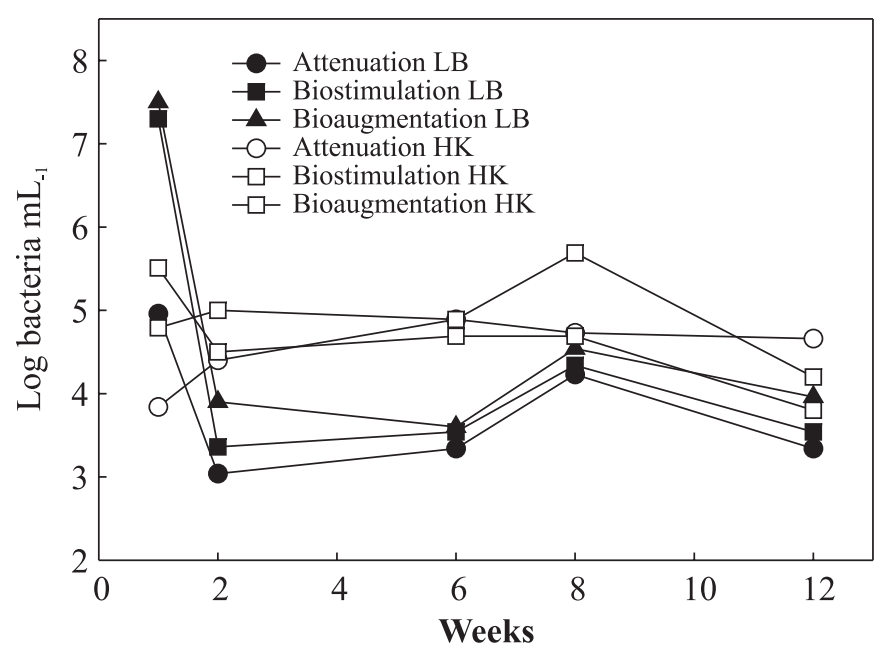

Figure 2. Number of diesel oil-degrading microorganisms in soils Long Beach (LB) and Hong Kong (HK) contaminated with diesel oil.

in the greatest number $\left(7.50\right.$ and $7.30 \log$ bacteria $\mathrm{mL}^{-1}$, respectively) at the beginning of incubation, compared to natural attenuation $\left(4.96 \log\right.$ bacteria $\left.\mathrm{mL}^{-1}\right)$. The ratio diesel oil-degrading microorganisms/heterotrophic microorganisms indicated that there are more heterotrophic microorganisms and that this ratio was the smallest in the Long Beach soil, mainly in the first two weeks. Thereafter, the ratios remained similar in both soils and were not affected by the bioremediation treatments (Table 3).

\section{DISCUSSION}

The highest rate of degradation of the light fraction of TPH $\left(\mathrm{C}_{12}-\mathrm{C}_{23}\right)$ was observed in the first two weeks of incubation in the Long Beach soil. During that period, more than $50 \%$ of the TPH was degraded, with a small and continual decrease in degradation until the end of the experiment (12 weeks). In the beginning, diesel oil-degrading microorganisms were stimulated by labile hydrocarbon sources (probably linear and open-chain hydrocarbons) that induced a high percentage of degradation. As those forms decreased, microbial populations had to use the more recalcitrant hydrocarbons (probably aromatic hydrocarbons with higher molecular weight) less efficiently. With the decrease in labile carbon sources, nutrients were most likely limited in supporting microbial growth. It is also possible that degradation of higher molecular weight hydrocarbons may produce toxic intermediates that can inhibit diesel-degrading microorganisms (5).

The soil collected from Long Beach, California showed the highest TPH degradation, reaching more than $70 \%$ degradation in 12 weeks of incubation. Upon bioaugmentation, this soil had a weekly rate of degradation of 58\%. The Hong Kong soil showed a weak response in biodegradation of its TPH components. The success of bioremediation is dependent of the level of metabolic and genetic adaptation of the microbial populations to their environment (4).

Biostimulation of soil microorganisms upon the addition of $\mathrm{N}$ and $\mathrm{P}$ resulted in the least degradation of diesel oil among the bioremediation treatments evaluated. By adding $\mathrm{N}$ and $\mathrm{P}$ these nutrients, the $\mathrm{C} / \mathrm{N}$ and $\mathrm{C} / \mathrm{P}$ ratios of the soil is closer to the bacterial $\mathrm{C} / \mathrm{N}$ and $\mathrm{C} / \mathrm{P}$ requirements (5). In our work, the less effect of biostimulation on diesel oil degradation might be due to nutrient limitation in terms of bioavailability.

The best performance in diesel oil degradation was with bioaugmentation of the Long Beach soil. In our study, the addition of a pre-selected microbial consortium degraded 73 to $75 \%$ of the light $\left(\mathrm{C}_{12}-\mathrm{C}_{23}\right)$ and heavy $\left(\mathrm{C}_{23}-\mathrm{C}_{40}\right)$ fractions of the TPH present in that soill, but had no effect on the Hong Kong soil. Diesel oil degradation was most related to the dehydrogenase activity than the number of diesel oil-degrading microrganisms. Thus, the best bioaugmentation performance can be approached by the use of microorganisms that are already present in the soil and increasing their abundance. With the increase of a specific microbial community and nutrient addition, this approach reduces cleanup time substantially. Indigenous microorganisms are well adjusted to their own environment. An immediate increase in the population density of these microbes could ensure rapid degradation of the pollutant. 


\section{RESUMO}

\section{Biorremediação de solos contaminados por óleo diesel}

Avaliou-se a degradação de hidrocarbonetos de petróleo (HP) em solos contaminados com óleo diesel através da atenuação natural, bioestimulação e bioaumentação. A bioaumentação apresentou a maior degradação da fração leve $(72,6 \%)$ e da fração pesada $(75,2 \%)$ de HP e a atenuação natural foi mais efetiva do que a bioestimulação. A maior atividade da dehidrogenase no solo Long Beach e Hong Kong foi observada nos tratamentos bioaumentação e atenuação natural, respectivamente. O número de microrganismos degradadores de diesel e a população de heterotróficos não foi influenciada pelas técnicas de biorremediação. A melhor performance para a biorremediação do solo contaminado com diesel foi obtida quando foram adicionados microrganismos pré-selecionados do ambiente contaminado.

Palavras-chave: atenuação natural, Bioaumentação, bioestimulação, hidrocarboneto de petróleo.

\section{REFERENCES}

1. Alef, K. Estimation of microbial activities: Dehydrogenase activity. In: Alef, K; Nannipieri, P. (eds.) Methods in applied soil microbiology and biochemistry. Academic Press, New York, 1995, p.228-231.

2. Barathi, S.; Vasudevan, N. Utilization of petroleum hydrocarbons by Pseudomonas fluorescens isolated from a petroleum-contaminated soil. Env. Int., 26:413-416, 2001.

3. Bento, F.M.; Camargo, F.A.O.; Okeke, B.C.; Frankenberger, W.T.Jr. Hydrocarbon-degrading bacteria diversity in soils contaminated with diesel oil. App. Soil Ecol., 2003 (submitted).

4. Devinny, J.; Chang, S.H. Bioaugmentation for soil bioremediation. In: Wise, D.L.; Trantolo, D.J. (eds.) Bioremediation of contaminated soils. Marcel Dekker, Inc., New York, 2000, p.465-488.

5. Frankenberger Jr., W.T. The need for a laboratory feasibility study in bioremediation of petroleum hydrocarbons. In: Calabrese, E.J.; Kostecki, P.T. (eds.) Hydrocarbon contaminated soils and groundwater. Lewis Pub., Boca Raton, FL, 1992, p.237-293.

6. Seklemova, E.; Pavlova, A.; Kovacheva, K. Biostimulation-based bioremediation of diesel fuel: Field demonstration. Biodegrad., 12:311-316, 2001. 